\title{
Application of water treatment technology with help solar and antimicrobial power to village communities Tanjung Selamat Sub-district Sunggal Districts Deli Serdang
}

\author{
Isnaini Nurwahyuni ${ }^{1 *}$, Riyanto Sinaga ${ }^{1}$, Rizky Yudha Pratama ${ }^{1}$, Fathurrahman ${ }^{1}$ \\ ${ }^{1}$ Faculty of Cultural Biology, Universitas Sumatera Utara, Medan, Indonesia \\ *Email: isnaininurwahyuni@yahoo.co.id
}

\begin{abstract}
The need for clean water is a challenge in rural areas, especially villages that have not yet been reached by the Regional Water Company (Perusahaan Daerah Air Minum,PDAM). One of the villages experiencing problems with the availability of clean water is Tanjung Selamat Housing Village, Deli Serdang Regency. The people in this village rely solely on ground water that comes from private bore wells. The problem faced is that the water is relatively high in turbidity, and the level of water sterilization is also very low because it contains microorganisms that cause disease such as dysentery, typhoid diarrhea and so on. An efforts to clean water using citrate have been made but the level of turbidity of the water is still above the threshold. To overcome this problem, appropriate technology is needed for water treatment to produce clean water. The purpose of this activity is to design and implement a technology to process raw water into clean water for public consumption. A design of antimicrobial water purification set with the help of solar power has been provided in Tanjung Selamat Deli Serdang Housing in 2019. The steps taken are surveying the existence of water standards, microbial laboratory testing and acidity test. Low quality raw water has obtained in the target villagewhere the water is high turbidity level, yellowish color, acidity level 6, 23 and contains coliform E.coli bacteria, so it requires processing before it is used as raw material for domestic purposes and drinking water. The application of purifying technology with the help of solar panels is able to convert raw water into clear water, has an acidity of 8.6 and is free of E. coli bacteria. The water produced is also alkaline so it is good for domestic consumption. Water user communities really feel the benefits of appropriate water purification technology developed in community service activities.
\end{abstract}

Keywords: Appropriate technology, Clean water, Community service, Turbidit-free, Water purification equipment.

\begin{abstract}
Abstrak
Kebutuhan akan ketersediaan air bersih menjadi tantangan di pedesaan, terutama desa yang belum dijangkau oleh Perusahaan Daerah Air Minum (PDAM). Salah satu desa yang mengalami masalah ketersediaan air bersih adalah Desa Tanjung Selamat Selamat, Kabupaten deli Serdang. Masyarakat di desa ini hanya mengandalkan air tanah yang berasal dari sumur bor pribadi. Permasalahan yang dihadapi adalah kekeruhan air relatif tinggi, dan tingkat sterilisasi air juga sangat rendah karena mengandung mikro organisme penyebab penyakit seperti disentri, tipus diare dan sebagainya. Usaha untuk membersihkan air menggunakan asam sitrat sudah dilakukan tetapi tingkat kekeruhan air masih diatas ambang batas. Untuk mengatasi permasalahan ini diperlukan teknologi tepat guna pengolah air mengahasilkan air bersih. Tujuan kegiatan ini adalah merancang dan menerapkan teknologi untuk mengolah bahan baku air menjadi air besih untuk konsumsi masyarakat. Pengabdiankepada masyarakat berupa penerapan teknologi penjernihan air dengan bantuan tenaga surya dan antimikroba dengan bantuan tenaga surya telah dilaksanakan di Perumahan Tanjung Selamat Deli Serdang Tahun 2019. Langkah yang dilakukan adalah survey keberadaan baku air, uji laboratorium mikroba dan uji derajat keasaman.Kualitas baku air sebelum dilaksanakan pengabdian kepada masyarakat tergolong rendah karena memiliki tingkat kekeruhan tinggi, warna kekuningan, derajat keasaman 6, 23 dan mengandung bakteri coliform E.coli, sehingga membutuhkan pengolahan sebelum digunakan menjadi bahan baku air untuk konsumsi domestik dan air minum. Penerapan teknologi tepat guna penjernih dengan bantuan panel surya mampu mengubah air baku yang menjadi air yang jernih, memilki derajat keasaman 8,6 dan bebas bakteri E.coli. Air yang dihasilkan juga bersifat alkali sehingga baik untuk konsumsi domestik. Masyarakat pengguna air sangat merasakan manfaat teknologi tepat guna penjernih air yang dikembangkan dalam kegiatan pengabdian kepada masyarakat ini.
\end{abstract}

Kata kunci: Air bersih, Alat penjernih air, Bebas kekruhan, Pengabdian kepada masyarakat, Teknologi tepat guna. 


\section{PENDAHULUAN}

Air merupakan sumber daya alam yang diperlukan untuk hajat hidup orang banyak, bahkan oleh semua makhluk hidup. Oleh karena itu sumber daya air tersebut harus dilindungi agar tetap dapat dimanfaatkan dengan baik oleh manusia dan makhluk hidup lainnya. Pemanfaatan air untuk berbagai kepentingan harus dilakukan secara bijaksana dengan memperhitungkan kepentingan generasi sekarang dan generasi mendatang (Nugroho, 2008). Kualitas air yang baik harus memenuhi syarat kualitas yang mencakup syarat fisik, kimia, mikrobiologi dan radioaktif sebagaimana standar yang diberlakukan Departemen Kesehatan RI yang tertuang dalam Peraturan Menteri Kesehatan Republik Indonesia No.492 /Menkes /Per /IV /2010 tentang Persyaratan Kualitas Air Minum. Kualitas air didefinisikan sebagai kadar parameter air yang dianalisis secara teliti sehingga menunjukkan mutu dan karakteristik air. Mutu dan karakteristik air ditentukan oleh jenis dan sifat-sifat bahan yang terkandung didalamnya (Suhendra et al., 2012).

Penyediaan air bersih di Indonesia masih tergolong rendah, terlebih untuk masyarakat yang berada di daerah pedesaan. untuk daerah pedesaan kebanyakan masyarakatnya menggunakan air tanah atau air permukaan untuk memenuhi kebutuhan mereka terhadap air (Endro, 2004). Dikarenakan keadaan yang tidak mendukung masyarakat untuk memperoleh air bersih yang menyebabkan masyarakat menggunakan air gambut (Kusnaedi, 2006).

Penyediaan air bersih Perumahan Tanjung Selamat Indah Desa tanjung Selamat Kabupaten Deli Serdang dikelola oleh lembaga PDAM. Cakupan pelayanan air bersih yang kurang menyebabkan masyarakat di Perumahan Tanjung Selamat Indah Desa tanjung Selamat Kabupaten Deli Serdang menggunakan air sumur bor sebagai sumber air yang digunakan. Aliran sungai Belawan yang mengelilingi Perumahan Tanjung Selamat Indah Desa tanjung Selamat Kabupaten Deli Serdang masih dimanfaatkan oleh masyarakat yang berada di sekitar sungai untuk memenuhi kebutuhan hidup sehari-hari, seperti MCK dan sebagai sumber air untuk pertanian. Selain itu, digunakan juga sebagai tempat pembuangan sampah dan air limbah domestik, baik secara langsung maupun tidak langsung untuk digunakan sebagai sumber air bor mempengaruhi kualitas dan bau air yang digunakan warga Perumahan Tanjung Selamat.

Sampai saat ini di daerah tersebut belum dilakukan pengolahan untuk memperbaiki kualitas pada air yang digunakan masyarakat, oleh karena itu kami ingin mengenalkan alat untuK mengedukasi masyrakat tentang pengelolaan air dan membantu persoalan yang terkait dengan ketersediaan air bersih yang dialami warga perumahan Desa Tanjung Selamat Kabupaten Deli Serdang

\section{METODE PELAKSANAAN}

Dalam program sosialisasi ini, digunakan beberapa metode, antara lain :

1. Metode ceramah, yaitu digunakan untuk memaparkan materi yang telah disusun oleh Tim Pelaksana

2. Metode Tanya Jawab, yaitu digunakan untuk merespon sejauh mana tingkat pemahaman peserta sosialisasi terhadap yang telah disampaikan oleh Tim Pelaksana Pengabdian Kepada Masyarakat.

3. Metode diskusi, yaitu pemateri dan peserta melakukan dialog yang membahas masalah penggunaan dan pemanfaatan alat untuk menghasilkan air bersih.

4. Metode Simulasi dan Praktek, yaitu digunakan untuk memperlihatkan instalasi dan penggunaan alat untuk menghasilkan air bersih tersebut dengan cara yang aman.

Materi pokok pembekalan yang diberikan dan tujuannya untuk masyarakat dapat dilihat dalam Tabel 1. 


\begin{tabular}{llll}
\hline & & \multicolumn{2}{c}{ Tabel 2.1. Materi Ceramah Sosialisasi } \\
\hline No & Jenis Materi & Tujuan Pemberian Materi & Peserta Pembekalan \\
\hline 1. & Kualitas air & $\begin{array}{l}\text { Masyarakat Mengetahui jenis dan kualitas } \\
\text { air di Perumahan Desa Tanjung Selamat }\end{array}$ & $\begin{array}{l}\text { Warga Perumahan Desa } \\
\text { Tanjung Selamat }\end{array}$ \\
2erdasarkan data. & $\begin{array}{l}\text { Masyarakat Mengetahuyi spesifikasi alat } \\
\text { 2. }\end{array}$ & $\begin{array}{l}\text { Desain model } \\
\text { peralatan } \\
\text { penyaringan air }\end{array}$ & $\begin{array}{l}\text { Penyaringan air minum yang baik. } \\
\text { Tanjung Selamat }\end{array}$ \\
Bahaya mikroba & $\begin{array}{l}\text { Masyarakat Mengetahui tentang bakteri } \\
\text { Escherechia coli khusunya pada air dengan } \\
\text { baik }\end{array}$ & $\begin{array}{l}\text { Warga Perumahan Desa } \\
\text { Tanjung Selamat }\end{array}$ \\
\hline
\end{tabular}

\section{HASIL DAN PEMBAHASAN}

\subsection{Peninjauan Lokasi}

Peninjauan lokasi dilakukan pada Juli 2019 untuk melihat kondisi nyata di lapangan serta memperkirakan posisi pemasangan penyaring dan kebutuhan alat-bahan. Berdasarkan pengamatan yang dilakukan diketahui bahwa visual air tampak kotor kecokelatan, menurut masyarakat, air yang berasal dari sumur bor yang mereka miliki berwarna kekuningan dan berminyak serta menghitam ketika di masak dan mengendap ketika bermalam. Penggunaan air dalam aktivitas cuci mencuci juga menyebabkan pakaian menjadi berwarna kekuningan. Lantai dan dinding kamar mandi kamar mandi masyarakat sekitar menjadi berkarat.

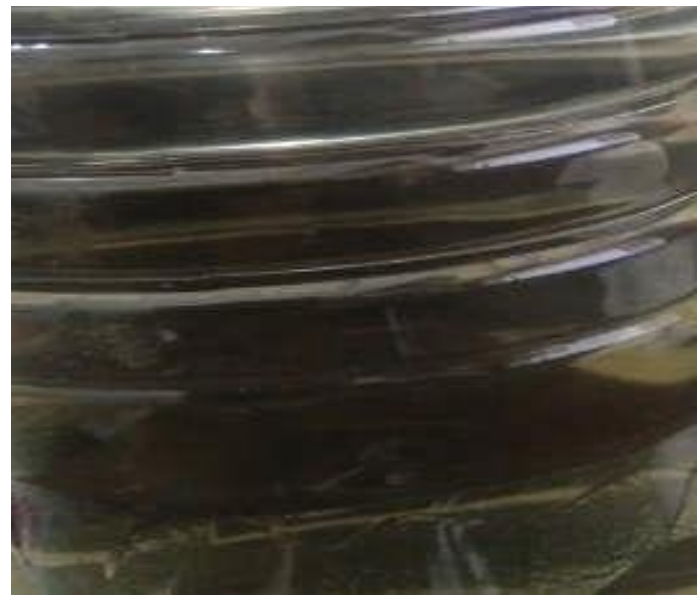

(A)

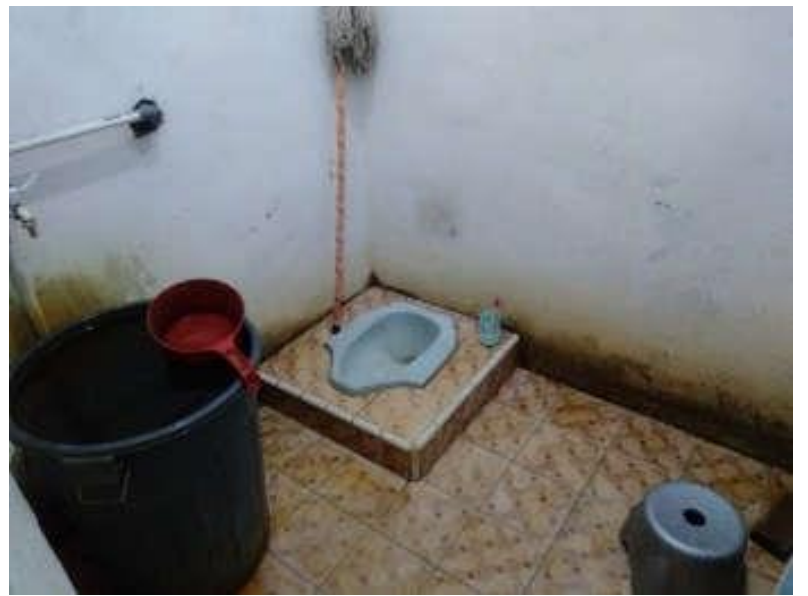

(B)

Gambar 3.1.1 (A) Keadaan air dan lantai kamar mandi masyarakat (B) Bak mandi

\subsection{Uji Kualitas Air}

Pada saat dilakukan kunjungan, tim mengambil sampel air untuk diukur kualitas air. Pengamatan visual menunjukkan bahwa air relatif keruh dan berwarna kekuningan.

\subsubsection{Uji Mikroba}

Berdasarkan analisis pengujian mikroba pada air yang digunakan masyarakat dalam aktivitas seharihari didapatkan bakteri E.coli yang jumlahnya sangat banyak sehingga membahayakan kesehatan masyarakat. Oleh karena itu, sistem penyaringan yang dibuat akan berfokus pada penurunan nilai kekeruhan air.dan pengurangan bakteri baktericoliforom.

Pengujian MPN (Most Probable Number) yang dilakukan terdiri dari 3 tahap, yaitu uji pendugaan (Persumtive test), uji konfirmasi (Confirmed test) dan uji kelengkapan (Completed test). Gambar A menunjukkan bahwa jumlah bakteri coliform mencapai 10.000 lebih dengan di 
dapatkannya E.coli pada sampel dengan menggunakan media EMB (Eosin Metilen Blue) yang didapatkan media berubah menjadi warna hijau metalik.

Semakin tinggi tingkat kontaminasi bakteri Coliform semakin tinggi pula risiko kehadiran bakteri patogen lain. Sebaliknya, semakin sedikit kandungan bakteri coliform semakin baik pula kualitas bakteriologis air minum (Natalia et al., 2014). Adanya bakteri coliform di dalam air minum mengindikasikan air minum tersebut telah terkontaminasi dengan polusi kotoran (Opacua et al.,2013). Kontaminasi bakteri Coliform pada air minum dapat berasal dari berbagai sumber yaitu bahan baku yang digunakan dari air yang sudah tercemar, pendistribusian yang kurang baik serta tempat air yang tidak higienis, Hasil pengujian air terhadap air yang telah disaring menunjukkan bahwa air tidak mengandung bakteri coliform, sehingga diasumsikan tidak adanya bakteri E.coli.

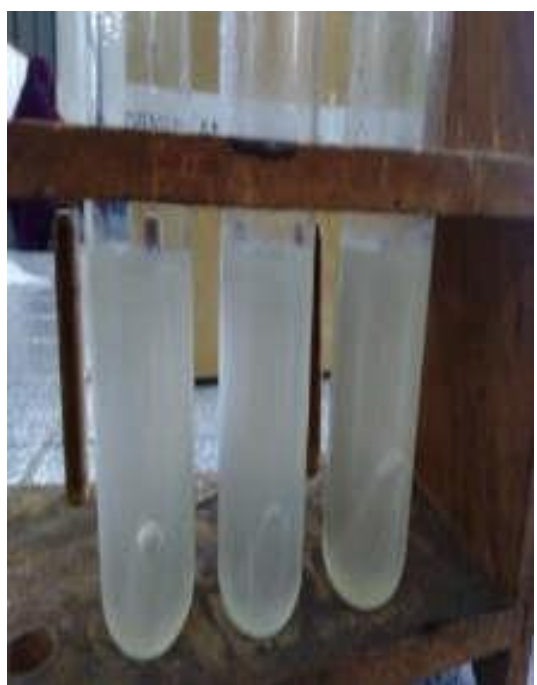

(A)

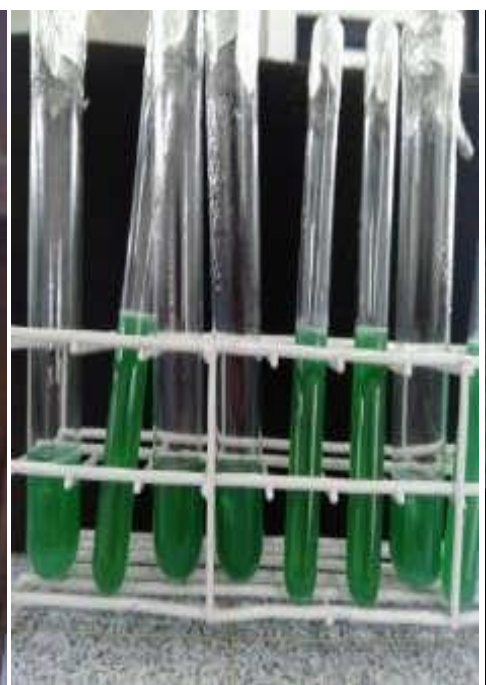

(B)

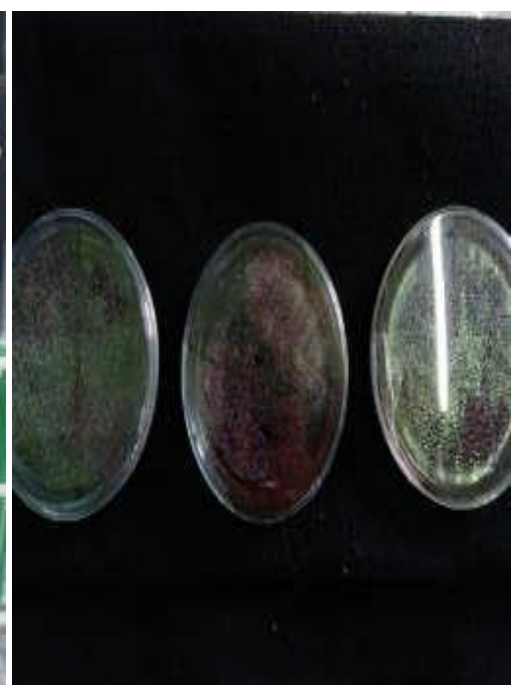

(C)

Gambar 3.2.1.1 (A). Uji pendugaan (Persumtive test) (B). Uji konfirmasi (Confirmed test) (C).Uji kelengkapan (Completed test) pada media EMB (Eosin Metilen Blue).

\subsection{Pembuatan Penyaring}

Penyaring anti mikroba dengan bantuan tata surya dibuat terlebih dahulu untuk mempermudah proses pemasangan yang akan dilakukan. Kegiatan pemasangan dilakukan pada bulan Mei-Juni 2019. Panel surya dipasang dibagian atas alat karena digunakan untuk menangkap energi matahari, sehingga pada saat listrik padam, alat masih dapat digunakan. Penyaring yang digunakan juga terdiri dari kapas dan arang yang berguna mengendapkan sisa kotoran air. Saringan mesh dipasang untuk mencegah kerikil dan pasir bercampur pada saat operasi ataupun pembersihan Elektroda juga digunakan untuk membantu proses penyaringan air. Air baku dipompa ke dalam box yang berisi elektroda sehingga pengotor dan karatan besi dapat terpisah dari air, $\mathrm{n}$ disaring melewati kerikil, saringan mesh, dan pasir aktif yang secara upflow sampai overflow 

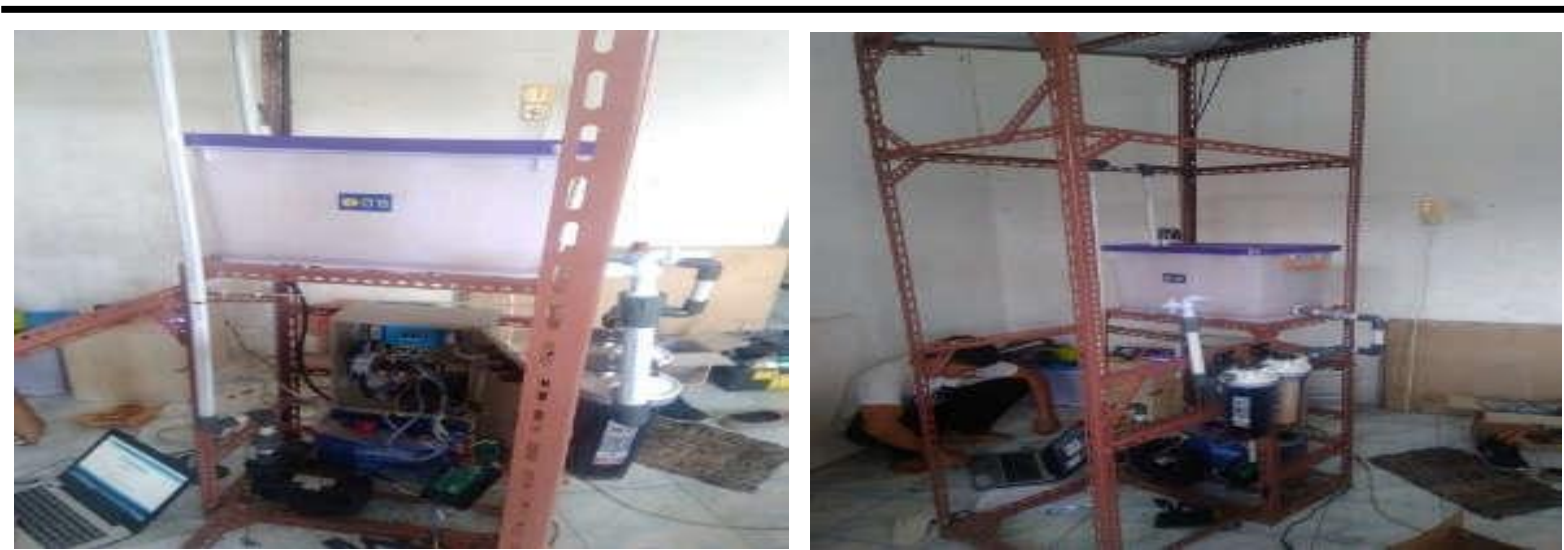

Gambar 3.3.1 (a) Sistem Penyaring (b) Instalasi alat penyaring yang Sudah Dipasang

Setelah pemasangan, masing-masing air keluaran dari setiap penyaringan dianalisis dan dibandingkan dengan kualitas air. Secara visual, perubahan kekeruhan air disajikan pada Gambar 4. Berdasarkan pengamatan visual diketahui bahwa sistem penyaringan yang telah dipasang berhasil menurunkan kekeruhan pada air.

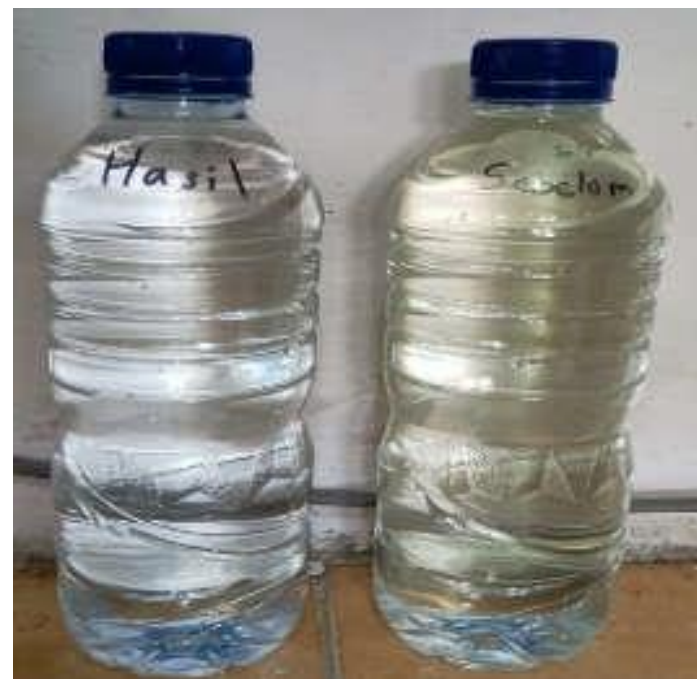

Gambar 3.3.2 Perbandingan Air Baku (kanan), Air Hasil Penyaringan (kiri)

Analisis kualitas air dilihat dari darajat keasaman dan kekeruhan pada sampel. Berdasarkan hasil pengujian kuantitatif diketahui bahwa sampel air baku tidak layak digunakan sebagai air bersih karena berwarna kuing keruh. Tabel derajat keasaman dapat dilihat pada Tabel 5.1 dibawah ini

Tabel 3.3.1 Hasil Derajat Keasaman Sampel

\begin{tabular}{ll}
\hline \multicolumn{1}{c}{ Sampel } & \multicolumn{1}{c}{ Derajat Keasaman } \\
\hline Air baku & 6,23 \\
Air setelah penyaringan & 8,6 \\
\hline
\end{tabular}

Dari tabel didapatkan bahwa air yang disaring bersifat alkali yaitu derajat keasaman basa. Air alkali dapat menjaga hidrasi tubuh, menetralisir kelebihan asam dalam tubuh, mengendalikan tekanan daqrah dan gula darah dan menjaga kesehatan tulang, sehingga air yang disaring dapat dikonsumsi.

Menurut Wan-Jun (2013), air alkali terionisasi dapat menghilangkan oksigen aktif dan melindungi DNA dari kerusakan oksidatif.Oksigen aktif atau radikal bebas yang dianggap menyebabkan kerusakan oksidatif yang luas untuk makromolekul biologis, yang membawa 
berbagai penyakit serta penuaan.Senyawa ideal untuk menghilangkan oksigen aktif adalah 'hidrogen aktif',sehingga air alkali merupakan air yang baik untuk dikonsumsi.

\section{Pengujian Kadar Fe Dan Mn Pada Sampel}

Pengujian kadarFe dan Mn dilakukan untuk mengetahui sampel air yang digunakan oleh masyarakat mengandung kadar Fe dan Mn yang baik atau terlalu tinggi sehingga membahayakan kesehatan. Hasil pengujian dapat dilihat pada Tabel 3.

Tabel 3.3.2 Pengujian Kadar Fe Dan Mn Pada Sampel

\begin{tabular}{cccc}
\hline parameter & Satuan & Hasil uji sebelum & Hasil uji sesudah \\
\hline $\mathrm{Fe}$ & $\mathrm{mg} / \mathrm{L}$ & 1.058 & 0.640 \\
$\mathrm{Mn}$ & $\mathrm{mg} / \mathrm{L}$ & 0.824 & 0.630 \\
\hline
\end{tabular}

Berdasarkan Tabel 3 didapatkan bahwa air yang disaring menggunakan alat penjernih mengalami penurunan kadar Fe dan Mn. Kadar Fe air baku turun $70 \%$ yaitu dari $1.058 \mathrm{mg} / \mathrm{L}$ menjadi $0.640 \mathrm{mg} / \mathrm{L}$ dan kadar Mn turun menjadi 31\%yang sebelumnya $0.824 \mathrm{mg} / \mathrm{L}$ turun menjadi $0.630 \mathrm{mg} / \mathrm{L}$. Namun ini belum dapat digunakan menjadi air minum yang layak langsung di konsumsi dikarenakan menurut PP No.20 Tahun 1990mengenai kadar (Fe) dalam air minum maksimum yang diperbolehkan adalah $0,3 \mathrm{mg} / \mathrm{L}$, dan kadar Mangan $(\mathrm{Mn})$ dalam air minum yang dibolehkan adalah $0,1 \mathrm{mg} / \mathrm{L}$,sehingga diperlukan adanya usaha untuk menurunkan kadar Fe dan Mn pada air kembali.

\subsection{Sosialisasi Sitem Penyaring}

Kegiatan pengabdian masyarakat ini juga disertai dengan sosialisasi kepada warga di sekitar perumahan tanjung selamat yang dilakukan melalui presentasi (disajikan pada Gambar 5). Hal itu dilakukan untuk memberikan pemahaman kepada warga tentang mekanisme kerja, komponen penyusun alat penyaring, serta cara penyusunan dan perawatannya. Pemberian ilmu tentang bahaya bakteri dan kondisi air yang baik juga dilakukan. Masyarakat diberi penjelasan bahwa alat penyaring dapat dibongkar pasang karena isi media saring membutuhkan perawatan. Pembersihan media saring perlu dilakukan secara rutin, yaitu tiga bulan sekali. Pembersihan media saring dilakukan dengan membilas media saring secara terus menerus sampai semua kotoran yang tertahan dapat dihilangkan.

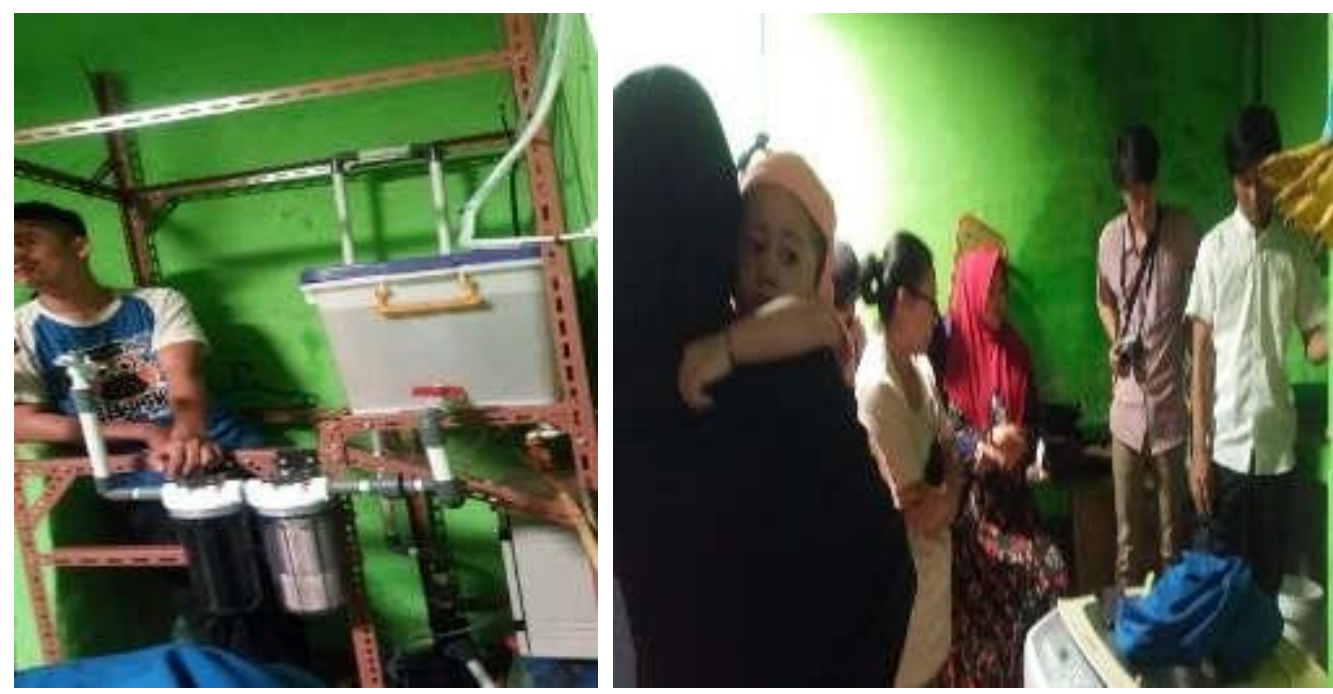

Gambar 3.4.1 Tim Melakukan Sosialisasi kepada Warga 


\section{KESIMPULAN}

Kegiatan pengabdian masyarakat di telah berhasil dilaksanakan Desa Tanjung Selamat Kecamatan Sunggal Kabupaten Deli Serdang. Sistem penyaring anti mikroba dengan bantuan tata surya berhasil menurunkan jumlah bakteri coliform dan meningkatkan derajat keasaman air, sehingga dapat digunakan sebagai air minum alkali. Penurunan kadar $\mathrm{Fe}$ dan Mn juga terjadi namun hasilnya belum sesuai dengan PP Tahun 1990 sehingga diperlukan adanya usaha untuk menurunkan kadar Fe dan Mn pada air kembali..

\section{UCAPAN TERIMAKASIH}

Segala puji dan syukur kami panjatkan kehadirat Tuhan Yang Maha Kuasa yang telah memberikan kesempatan kepada Tim untuk melaksanakan Pengabdian Masyarakat sebagai salah satu kegiatan dari Tri Dharma Perguruan Tinggi. Pengabdian Mono Tahun Regular Non PNBP ini diselenggarakan karena air di Desa Tanjung Selamat, Kecamatan Sunggal, Kabupaten Deli Serdang keruh dan tidak higienis. Dengan demikian Cara penjernihan air dengan tenaga surya dan antimikroba antimikroba dapat diterapkan. Penggunaan energi matahari diharapkan dapat memanfaatkan agar dapat mengurangi penggunaan listrik.

Kegiatan ini dapat dilaksanakan karena adanya dukungan dari berbagai pihak. Oleh karena itu ijinkan kami menyampaikan rasa terima kasih kepada Rektor Universitas Sumatera Utara. Dekan Fakultas Matematika Dan Ilmu Pengetahuan Alam, Universitas Sumatera Utara .Ketua Lembaga Pengabdian Pada Masyarakat Universitas Sumatera Utara. Ketua Program Studi Biologi Fakultas Matematika Dan Ilmu Pengetahuan Alam, Universitas Sumatera Utara. Mitra dan semua pihak yang telah membantu dan berperan aktif pada kegiatan ini

\section{DAFTAR PUSTAKA}

Endro S, Nurandani H, Budiyono. (2004),Perencanaan Instalasi Pengolahan Air Limbah Hotel Sahid Kusuma Raya Surakarta. Majalah TEKNIK Tahun XXIV Edisi 2, ISSN No. 08521697.

Kusnaedi. (2006). Mengolah Air Gambut Dan Air Kotor Untuk Air Minum. Jakarta :Penebar Swadaya.

Natalia LA, Bintari SH, Mustikaningtyas D. (2014). Kajian Kualitas Bakteriologis Air Minum Isi Ulang Di Kabupaten Blora. Unnes Journal of Life Science, 3(1), 31-8.

Nugroho, S.P. (2008). “Analisis Kualitas Air Danau Kaskade Sebagai Sumber Imbuhan Waduk Resapan di Kampus UI Depok”. Jurnal Sains dan Teknologi Indonesia, 10. 99-105.

Opacua FC, Purwijantiningsih LME, Pranata S. (2013). Kandungan coliform dan klorin es batu di Yogyakarta. Jurnal Ilmiah Biologi.:9.

Suhendra D.Satryo, Irnawati M, Devi N.S, (2012). Analisis Kualitas Air Gambut Dan Keluhan Kesehatan Pada Masyarakat Di Dusun Pulo Gombut Desa Suka Rame Baru Kecamatan Kuala Hulu Kabupaten Labuhan Batu Utara Tahun 2012. Universitas Sumatera Utara.

Winarti. W, Krisnamurti, K Aswatama ,(2014). Ibm Warga Desa Darungan Yang Menghadapi Masalah Air Bersih. Laporan IPTEK Pengabdian Mayarakat. Surabaya. 